\title{
Antimicrobial Action of the Essential Oil of Lippia gracilis Schauer
}

\author{
Cynthia Cavalcanti de Albuquerque ${ }^{1 *}$, Terezinha Rangel Camara ${ }^{2}$, Rosa de Lima Ramos \\ Mariano $^{2}$, Lilia Willadino ${ }^{2}$, Cristiano Marcelino Júnior ${ }^{2}$ and Cláudia Ulisses ${ }^{2}$ \\ Universidade do Estado do Rio Grande do Norte - UERN; Departamento de Ciências Biológicas; C. P. 70; \\ 59.610-090; cynthiaca@uol.com.br; Mossoró - RN - Brasil. ${ }^{2}$ Universidade Federal Rural de Pernambuco - \\ UFRPE; Recife - PE -Brasil
}

\begin{abstract}
Antimicrobial activity of the essential oil (EO) of Lippia gracilis Schauer over fungi and heliconia endophytic bacteria was evaluated. For the fungi Geotrichum candidum; Trichoderma viride; Torula herbarum; Paecillomyces sp.; Fusicoccum sp.; P. aeruginens; Curvularia lunata; Aspergillus nidulans; A. flavus; and A. niger mycelial discs were inoculated in PDA medium with oil $\left(0 ; 420 ; 440 ; 460 ; 480\right.$ e $\left.500 \mu \mathrm{L} \mathrm{L} \mathrm{L}^{-1}\right)$. The inhibition percentage in $420 \mu \mathrm{L}$ $L^{-1}$ was $100 \%$ for all fungi, except for $\mathrm{C}$. lunata and A. niger, which was $95.58 \%$ and $89.40 \%$, respectively. In other experiment, a suspension of the Salmonella choleraceuis-diarizonae, Enterobacter asburiae, Bacillus thuringiensis, B. pumilus, B. cereus, Klebsiella pneumoniae, and E. hormaechei was individually added to the solid NYDA medium dishes. In each dish, wells were drilled in medium and filled with water or EO $\left(420 \mu L L^{-1}\right)$. The diameter of the inhibition halo was assessed. K. pneumoniae was the bacterial species less sensitive and $\mathrm{E}$. hormaechei was the most sensitive.
\end{abstract}

Key words: Micropropagation, contamination, monoterpenes

\section{INTRODUCTION}

Microbial contamination is the main cause of plant losses in culture media in laboratories of plant tissue culture (Leifert et al., 1994; Niedz and Baushier, 2002). In many cases, the contaminating sources are not easily determined; however, the most common ones are associated with microorganisms of the environment and of the manipulating individual. A frequent form of penetration of spores and cells of microorganisms into the work environment is through air currents that are brought by the air conditioning equipment, remaining in the environment due to inadequate asepsis conditions (Leifert et al., 1994). Among the most common microorganisms, the fungi are frequently detected and are highly detrimental, as they grow right in the nutritional medium, competing with the plants for the nutrients of the medium, besides producing phytotoxic metabolites (Leifert et al., 1994). In many cases the superficial disinfections that precede the inoculation of the explants are inefficient. This problem may be due to the inactivity of the disinfestants usually used, or due to the fact that the microorganisms protect themselves in the interior of the vegetable tissue (Leifert and Woodward, 1998). Endophytic contamination, that is, microorganisms that colonize vegetable tissues internally, are also harmful for in vitro plant cultures. After viruses,

\footnotetext{
${ }^{*}$ Author for correspondence
} 
the greatest references are for bacteria, considered by many authors as contaminants that cause more serious problems since; in general, they are systemic and hard to eliminate (Leifert et al., 1994; Capó, 1998). Endophytic bacteria may cause death of the cultures, growth retardation, necrosis, and alterations in the morphogenetic potential, as well as reduction in the rate of in vitro multiplication and rooting (Levin et al., 1996). These endogenous contaminations keep plants with high commercial potential and low productivity, such as some species of heliconia, for example, from becoming established in vitro (Santos, 1999; Dias and Rodrigues, 2001).

One possible solution for this problem would be the addition of antibiotic substances to the culture media; however, some of them possess bacteriostatic rather than bactericide action (Grattapaglia and Machado, 1998). Furthermore, when used in efficient concentrations against the contamination, they are phytotoxic (Nannetti, 1994) and may also induce resistance to the contaminating organisms.

In the past, the antimicrobial properties of aromatic plant extracts, particularly the essential oils, have been studied (Isman, 2000; Rassoli and Mirmostafa, 2003). Some species of the Lippia gender are characterized by the presence of essential oils, with antimicrobial activity, due to the phenolic monoterpenes thymol and carvacrol. Among these species, L. gracilis, native of the Brazilian Northeast, is highlighted because it presents high contents of these monoterpenes (Matos et al., 1999).

Thus, the objective this work was to assess the effect of the essential oil of $L$. gracilis over contaminating fungi of the air and endophytic bacteria of the heliconias.

\section{MATERIALS AND METHODS}

\section{Extraction and analysis of the essential oil}

The essential oil (EO) was extracted from leaves of $L$. gracilis plants brought from the town of Petrolândia, PE. The extraction was performed using a Clevenger apparatus according to Rassoli and Mirmostafa (2003). The identification of the components of the essential oil was performed by gas chromatography attached to the mass spectrometer (GC - MS).

Isolation of endophytic bacteria from the caulinary shoots of heliconias
Rhizomes of the hybrid Heliconia psittacorum $x$ $H$. spathocircinata var. Golden Torch and of the species $H$. latispatha, $H$. caribea, $H$. bihai and $H$. rostrata were collected from the Mulata farm, located in the town of Camaragibe, $20 \mathrm{~km}$ from Recife. For the extraction and inoculation of the caulinary shoots, the Santos methodology (1999) was followed. The explants were inoculated in MS (Murashige and Skoog, 1962) medium, without phytoregulators. The contaminants observed in association with the caulinary shoots were transferred to the NYDA medium: yeast-dextroseagar nutritive extract (Pusey and Wilson, 1984). Colonies were separated according to color, size and shape, and purified in NYDA medium. Then, the isolates were transferred to test tubes containing the same culture medium and stored at $4^{\circ} \mathrm{C}$. The isolates were identified in the National Center of Environmental Research, (Embrapa/CNPMA), Jaguariúna, SP by Dr. Itamar S. Melo.

\section{Fungi Isolation}

Petri dishes containing the MS medium were opened for 3 minutes in the sterilization room of the Plant Tissue Culture Laboratory. The aim was to collect suspended microorganisms in the place. After 8 days, the fungi developed in the Petri dishes were stored individually in test tubes containing the PDA (potato-dextrose-agar) medium and stored at $4{ }^{\circ} \mathrm{C}$. For the identification of the fungi, microcultures were prepared and their structures were observed in the microscope through the preparation of slides colored with Amann blue, considering the morphology of the conidia and their formation in the conidiophores (Menezes and Silva-Hanlin, 1997).

\section{Inhibitory concentration of the essential oil}

For the selection of the minimum inhibitory concentration (MIC), the bacterial isolates obtained from the caulinary shoots of heliconias cultivated in vitro were used. Qualitative tests were performed in order to select a minimum dosage of the essential oil of $L$. gracilis capable of inhibiting all of the isolates. The bacterial growth was transferred by streaking with platinum loop on NYDA and MS media, containing oil in the concentrations of $0 ; 100 ; 200 ; 300 ; 400 ; 500 ; 600$; 700 and $800 \mu \mathrm{L} \mathrm{L}^{-1}$. Between the concentrations of 400 and $500 \mu \mathrm{L} \mathrm{L}^{-1}$ of oil, some species presented growth in the NYDA medium. Due to this fact, following the same procedure, the 
isolates were plated in NYDA medium with 420; 440; 460; 480 and $500 \mu \mathrm{L} \mathrm{L}^{-1}$ of oil. Growth inhibition of isolated bacteria was assessed and the smallest dosage capable of inhibiting all of the species evaluated was selected. The experiment was entirely casualized with 4 repetitions per dosage assessed.

\section{Action of $L$. gracilis oil over endophytic bacteria isolated from heliconias cultivated in vitro}

The suspensions were prepared in Petri dishes from 36-h long bacterial growth in NYDA, adding $10 \mathrm{ml}$ of sterilized distilled water (SDW) per dish. The suspensions were transferred into test tubes and homogenized in Vortex mixer, adjusting the concentration at $580 \mathrm{~nm}$ for $\mathrm{A}_{580}=0.7$ in photocolorimeter. Aliquotes of $3.2 \mathrm{~mL}$ of the suspension of each species were added, individually, to $80 \mathrm{~mL}$ in NYDA medium, which were poured onto Petri dishes. In the center of each dish, wells of approximately $3 \mathrm{~mm}$ deep $\mathrm{x}$ $5 \mathrm{~mm}$ in diameter were made and filled with $8.4 \mu \mathrm{L}$ of the pure EO (dosage equivalent to $420 \mu \mathrm{L}$ of oil $\mathrm{L}^{-1}$ of the medium, or $420 \mathrm{ppm}$ ). In the control treatment, the wells were filled with $8.4 \mu \mathrm{L}$ of sterilized de-ionized water. The variable assessed was the diameter $(\mathrm{cm})$ of the inhibition halo, measured $24 \mathrm{~h}$ after the beginning of the experiment. The experimental design was entirely casualized with 4 repetitions per treatment. The experimental unit was one well per dish.

The inhibitory action of the oil in liquid medium was also assessed. For this, $0.2 \mathrm{~mL}$ aliquotes of the bacterial suspension $\left(\mathrm{A}_{580}=0.7\right)$ were added to test tubes with screw-on lids containing $5 \mathrm{~mL}$ of NYD medium. Treatments constituted $420 \mu \mathrm{L}$ of pure EO and $420 \mu \mathrm{L}$ of SDW (control). For absolute control test tubes containing NYD medium without bacteria were assessed. The absorbance was assessed $24 \mathrm{~h}$ after the beginning of the experiment. The percentage of inhibition of growth of the bacterial isolates submitted to the treatment with oil was determined through the application of the formula: $\mathrm{I}=\left[\left(\mathrm{CB}_{\mathrm{c}}-\mathrm{CB}_{\mathrm{t}}\right) / \mathrm{CB}_{\mathrm{c}}\right]$ x 100; where $\mathrm{I}=$ percentage of inhibition; $\mathrm{CB}_{\mathrm{c}}=$ bacterial growth in the control; $\mathrm{CB}_{\mathrm{t}}=$ bacterial growth in the treatment. The experimental design was entirely casualized with 4 repetitions per treatment. The experimental unit was one isolate per tube. The data were submitted to analysis of variance (ANOVA) and the means compared by the Tukey test $(\mathrm{p} \leq 0.05)$.

\section{Action of $\boldsymbol{L}$. gracilis oil over fungi}

Mycelial discs of each isolate with approximately $3 \mathrm{~mm}$ of diameter were taken from cultures with 5 days in PDA medium and inoculated in the center of a Petri dish containing PDA medium with oil of $L$. gracilis in the following concentrations: 0; $420 ; 440 ; 460 ; 480$ and $500 \mu \mathrm{L} \mathrm{L}^{-1}$. Evaluations began $48 \mathrm{~h}$ after the setup of the equipment and the variables evaluated were mycelial growth and sporulation. The mycelial growth was evaluated with the aid of a milimetrized ruler through daily measures of the diameter of the colonies perpendicularly. To determine the inhibition percentage, the data of the individual mycelial linear growth of each fungus was used, through the application of the adapted formula of Edington et al. (1971): $\mathrm{I}=\left[\left(\mathrm{CF}_{\mathrm{c}}-\mathrm{CF}_{\mathrm{t}}\right) / \mathrm{CF}_{\mathrm{c}}\right] \times 100$; where $\mathrm{I}=$ percentage of inhibition; $\mathrm{CF}_{\mathrm{c}}=$ growth of the fungus in the control; $\mathrm{CF}_{\mathrm{t}}=$ growth of the fungus in the treatment. The sporulation was assessed through spore count in a Neubauer chamber. The experimental design was entirely casualized with 5 repetitions for each fungus assessed.

\section{RESULTS AND DISCUSSION}

The pure oil of $L$. gracilis in the concentration of $420 \mu \mathrm{L} \mathrm{L}^{-1}$ of the medium was efficient in inhibiting the bacteria tested (Table 1).

In the initial tests in which the pure oil was mixed with the culture media for the selection of the minimal inhibitory dosage, it was observed that the NYDA medium was more favorable to the bacterial growth than the MS medium. In the treatment with $400 \mu \mathrm{L} \mathrm{L}^{-1}$ of oil in the NYDA medium, growth of Klebsiella pneumoniae (HB 1), Enterobacter hormaechei (HB 2) and Bacillus pumilus (HB 5) was observed. On the other hand, in the MS medium, all the isolates were inhibited in the concentration of $400 \mu \mathrm{L} \mathrm{L}^{-1}$ (Table 2). Yeast extract-based and peptone-based culture media are richer and favor the growth of microorganisms. Although the basic nutritive medium for the culture work was the MS, the NYDA medium could be recommended for index tests in plants propagated in vitro, since bacteria generally multiplied faster in NYDA when compared to the MS (Niedz and Baushier, 2002). There are cases in which bacteria do not present visible growth in the MS medium, despite being in the explant. However, when the bacteria manifest 
growth during the process of micropropagation of plants, this could cause mass proliferation of these microorganisms in the laboratories (Leifert and Woodward, 1998). The use of a mixture of isotiazolone biocide substances in MS medium inhibited the growth of microorganisms for 90 days. However, greater quantities of the biocide were required to control the microbial growth in a nutritive medium supplemented with yeast and peptone extract, which were components of the NYDA medium (Niedz, 1998).

Table 1 - Bacterial isolates obtained from a hybrid and from four species of Heliconia

\begin{tabular}{lcc}
\hline \multicolumn{1}{c}{ Host } & Code & Bacteria \\
\hline $\begin{array}{l}\text { Heliconia psittacorum } x \text { H. spathocircinata } \text { var. Golden } \\
\text { Torch }\end{array}$ & GT 1 & Salmonela choleraceuis-diarizonae \\
H. psittacorum $x$ H. spathocircinata var. Golden Torch & GT 5 & Enterobacter asburiae \\
H. latispatha & LT 2 & Bacillus thuringiensis \\
H. latispatha & LT 5 & Bacillus pumilus \\
H. caribea & CB 1 & B. pumilus \\
H. bihai & HB 1 & Klebsiella pneumoniae \\
H. bihai & HB 2 & Enterobacter hormaechei \\
H. bihai & HB 5 & B. pumilus \\
H. rostrata & RT 4 & Bacillus cereus \\
\hline
\end{tabular}

In face of the results, the dosages $420 ; 440 ; 460$; 480 and $500 \mu \mathrm{L} \mathrm{L}^{-1}$ were tested, and concentration $420 \mu \mathrm{L}$ was selected as the minimal dosage capable of inhibiting the growth of all of the bacterial isolates in medium NYDA.

In the activity test of the oil of $L$. gracilis in the minimum inhibitory concentration $\left(420 \mu \mathrm{L} \mathrm{L}^{-1}\right)$ in wells in the medium NYDA, the inhibition of the growth of all of the bacterial isolates assessed was checked, despite there being significant difference between them as to the diameter of the inhibition halo (Table 3). In the control dishes there was no inhibition of the growth. E. hormaechei (HB 2) was the most sensitive to the oil, whereas the $K$. pneumoniae (HB 1) was the least affected. Demetzos et al. (2001) also observed that the species K. pneumoniae behaved as resistant to the essential oils of Origanum calcaratum and $O$. scabrum. Some papers report that the bacteria species respond differently to the diverse substances extracted from plants (Ahmed et al., 1994; Lindsay et al., 2000; Reddy et al., 2001).

Test runs to verify the effect of the essential oils of Inula helenium and Rosmarinus officinalis over eight bacterial species revealed that only Staphylococcus aureus and Streptococcus pyogenes were completely inhibited, while Streptococcus faecalis did not show sensitivity to these essential oils, thus evidencing that a variation of behavior could occur among species of the same gender (Boatto et al., 1994).

Table 2 - Antibacterial activity of the oil of Lippia gracilis in media NYDA and MS

\begin{tabular}{|c|c|c|c|c|c|c|c|c|c|c|}
\hline \multirow[t]{3}{*}{ Bacteria } & \multirow[t]{3}{*}{ Code } & \multicolumn{9}{|c|}{ Nyda/ Ms } \\
\hline & & \multicolumn{9}{|c|}{ Concentrations $\mu \mathrm{L}(\mathrm{v}: \mathrm{v})$} \\
\hline & & 0 & 100 & 200 & 300 & 400 & 500 & 600 & 700 & 800 \\
\hline Salmonela choleraceuis-diarizonae & GT 1 & $+/+$ & $+/+$ & $+/+$ & $+/+$ & $-1-$ & $-1-$ & $-1-$ & $-/$ & $-1-$ \\
\hline Enterobacter asburiae & GT 5 & $+1+$ & $+1+$ & $+/+$ & $+1+$ & $-1-$ & $-1-$ & $-1-$ & $-1-$ & $-1-$ \\
\hline Bacillus thuringiensis & LT 2 & $+1+$ & $+/+$ & $+/+$ & $+/+$ & $-1-$ & $-1-$ & $-1-$ & $-1-$ & $-1-$ \\
\hline B. pumilus & LT 5 & $+/+$ & $+1+$ & $+/+$ & $+/+$ & $-1-$ & $-1-$ & $-1-$ & $-1-$ & $-1-$ \\
\hline B. pumilus & CB 1 & $+/+$ & $+1+$ & $+/+$ & $+/+$ & $-1-$ & $-1-$ & $-1-$ & $-1-$ & $-1-$ \\
\hline Klebsiella pneumoniae & HB 1 & $+/+$ & $+1+$ & $+/+$ & $+1+$ & $+1-$ & $-1-$ & $-1-$ & $-1-$ & $-1-$ \\
\hline E. hormaechei & HB 2 & $+1+$ & $+/+$ & $+/+$ & $+1+$ & $+1-$ & $-1-$ & $-1-$ & $-1-$ & $-1-$ \\
\hline B. pumilus & HB 5 & $+/+$ & $+1+$ & $+/+$ & $+1+$ & $+1-$ & $-1-$ & $-1-$ & $-1-$ & $-1-$ \\
\hline B. cereus & RT 4 & $+1+$ & $+1+$ & $+1+$ & $+1+$ & $-1-$ & $-1-$ & $-1-$ & $-1-$ & $-1-$ \\
\hline
\end{tabular}

(+) bacterial growth (-) inhibition of the bacterial growth 
$\underline{\text { Table } 3 \text { - Diameter of zone of inhibition }(\mathrm{cm}) \text { at } 420 \mu \mathrm{L} \mathrm{L}^{-1} \text { concentration of the Lippia gracilis oil }}$

\begin{tabular}{lccc}
\hline \multicolumn{1}{c}{ Bacteria } & Code & Diameter of zone of inhibition & $\begin{array}{c}\text { Absorbance } \\
\left.\mathbf{A}_{\mathbf{5 8 0}}=\mathbf{0 . 7}\right) \\
\mathbf{\%} \text { Inhibition }\end{array}$ \\
\hline Enterobacter hormaechei & & & $77.7 \mathrm{a}$ \\
Bacillus cereus & HB 2 & $3.11 \mathrm{a}^{2}$ & $56.5 \mathrm{ab}$ \\
E. asburiae & RT 4 & $2.74 \mathrm{~b}$ & $48.4 \mathrm{~b}$ \\
Salmonela choleraceuis-diarizonae & GT 5 & $2.69 \mathrm{~b}$ & $45.3 \mathrm{~b}$ \\
B.pumilus & GT 1 & $2.63 \mathrm{~b}$ & $59.3 \mathrm{ab}$ \\
B.thuringiensis & LT 5 & $2.54 \mathrm{~b}$ & $59.9 \mathrm{ab}$ \\
B.pumilus & LT 2 & $2.51 \mathrm{~b}$ & $62.8 \mathrm{ab}$ \\
B.pumilus & HB 5 & $2.48 \mathrm{~b}$ & $53.9 \mathrm{ab}$ \\
Klebsiella pneumoniae & CB 1 & $2.41 \mathrm{~b}$ & $48.3 \mathrm{~b}$ \\
\hline
\end{tabular}

${ }^{1}$ Formula $\left(\mathrm{I}=\mathrm{CB}_{\mathrm{c}}-\mathrm{CB}_{\mathrm{t}} / \mathrm{CB}_{\mathrm{c}} \mathrm{x}\right.$ 100) $\mathrm{I}=$ percentage of inhibition; $\mathrm{CB}_{\mathrm{c}}=$ bacterial growth in the control; $\mathrm{CB}_{\mathrm{t}}=$ bacterial growth in the treatment. ${ }^{2}$ Averages followed by the same letters do not differ significantly by the Tukey test $(\mathrm{p} \leq 0.05)$.

In the liquid medium, the isolate HB2 behaved as more sensitive to the oil, having its growth inhibited in $77.7 \%$ (Table 3); however, it did not differ statistically from the isolates HB 5, LT 2, LT 5, RT4 and CB 1. On the other hand, the isolates GT $1(45.3 \%)$, HB $1(48.3 \%)$ and GT 5 (48.4\%) were less sensitive without differing among themselves.

There was a positive correlation in solid and liquid medium when the sensitivity of the isolates to the oil of L. gracilis (Table 3) was assessed. The isolate HB1 ( $K$. pneumoniae) behaved as less sensitive in both media, as it presented the smallest inhibition halo in solid medium and one of the smallest inhibition percentages in liquid medium. The isolate HB2 (E. hormaechei), which was the most sensitive to the oil in solid medium, also showed one of the highest percentages of inhibition in liquid medium. In a solid medium, the inhibition halo around the wells that contained the oil was quite visible. In liquid medium, the growth was more homogeneous. In some cases, the results differed according to the species of microorganism and to the consistency of the culture medium. Pellecuer et al. (1976), quoted by Rios et al. (1988), compared the activity of the essential oils of Thymus against E. coli and $S$. aureus and found that the oil was more active against $S$. aureus by the method of disc diffusion, whereas the $E$. coli showed highest sensitivity when a liquid medium was used. Besides the action of the oil, the peculiarity of bacterial growth in a medium increased with agar was also attributed to deficient physiological conditions, that is, the individuals competed among themselves for nutrients and for oxygen. The immobilization of the bacterial cells also decelerates the growth rate (Bakholdina et al., 2001). Although the test in liquid medium confirmed inhibition of growth of the bacterial isolates, the method of diffusion in agar has been the most used in studies of antimicrobial activity, due to the hydrophobic property of the essential oils (Rios et al., 1988).

Studies performed with other vegetable species, whose essential oil presented carvacrol and thymol in its chemical composition, showed results similar to those obtained in this work. Essential oils of $O$. calcaratum and $O$. scabrum, rich in carvacrol, were active against $S$. aureus and $S$. epidermidis (Demetzos et al., 2001). Similarly, oils extracted from two species of Thymus inhibited the growth of E. coli; S. aureus; B. subtilis and K. pneumoniae (Rassoli and Mirmostafa, 2003).

As for antifungal activity, the oil of $L$. gracilis showed to be efficient in inhibiting the fungi assessed in this work. The species resulting from isolation in laboratory were: Geotrichum candidum; Trichoderma viride; Torula herbarum; Paecillomyces sp.; Aspergillus nidulans; Fusicoccum sp.; Aspergillus flavus; Paecillomyces aeruginens; Curvularia lunata and Aspergillus niger. In $420 \mu \mathrm{L} \mathrm{L}^{-1}$ concentration, the percentage of inhibition of the mycelial growth for $C$. lunata and A. nidulans was 95.58 and $89.40 \%$, respectively (Fig. 1). The other species were inhibited completely (percentage of inhibition $=$ $100 \%$ ). The antifungal activity of certain essential oils whose main constituents are thymol and carvacrol, has already been determined by several 
researchers, including for some genders of fungi assessed in this work (Dwivedi and Singh, 1998; Arras and Usai, 2001; Lambert et al., 2001; Daferera et al., 2003; Pina-Vaz et al., 2004; Sokmen et al., 2004). As for sporulation, at a concentration of $420 \mu \mathrm{L} \mathrm{L}^{-1}$ there was no production of spores of the fungi assessed, except for A. nidulans (Table 4). In the control treatment, all of the species assessed developed in the period of five days, covering completely the medium surface.

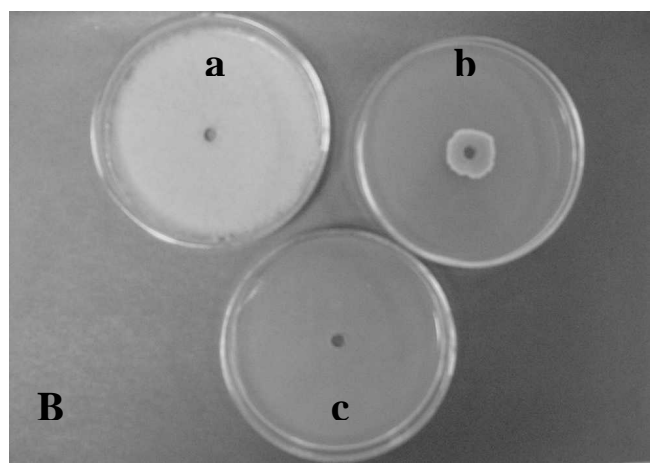

Figure 1 - Mycelial growth of the fungi Curvularia lunata (A) and Aspergillus nidulans (B), submitted to the oil of Lippia gracilis in concentrations ranging from 0.0 $\mu \mathrm{L} \mathrm{L}^{-1}$ (a); $420 \mu \mathrm{L} \mathrm{L}^{-1}$ (b); $440 \mu \mathrm{L} \mathrm{L}^{-1}$ (c).

Table 4 - Sporulation of the fungus Aspergillus nidulans, submitted to treatment with or without essential oil of Lippia gracilis.

\begin{tabular}{lcc}
\hline & Treatment & Aspergillus nidulans \\
\hline Control & & $31.39 \times 10^{6} \mathrm{a}^{1}$ \\
With oil & $\left(420 \mu \mathrm{L} \mathrm{L}^{-1}\right)$ & $7.72 \times 10^{6} \mathrm{~b}$ \\
\hline
\end{tabular}

${ }^{1}$ Significant difference by the Student test between the two averages of spore number.

Most part of the essential oils possesses activity against fungi and bacteria due to the presence of monoterpenes. The main constituents of the essential oil of $L$. gracilis used in this work were carvacrol (41.77\%) and thymol (10.13\%), classified as phenolic monoterpenes (Rasooli and Mirmostafa, 2003). These compounds have been studied even against food pathogens, such as Bacillus cereus (Periago et al., 2002). The essential oil of Thymus vulgaris, with percentages of thymol (18.1\%) and carvacrol (8.9\%), lower than those obtained in this work, was highly efficient in the reduction of gray mold and soft rot in strawberries, caused by the fungi Botrytis cinerea and Rhizopus stolonifer, respectively. These volatile compounds act in the reduction of the conidial germination, causing subsequent death of the fungus (Reddy et al., 1997). Studies done with oregano also confirmed the antifungical action of its oil, due to the presence of thymol and carvacrol. The phenolic monoterpenes inhibited the formation of the germinative tube of Candida albicans, besides inhibiting the growth of the yeast (Manohar et al., 2001). Other studies to assess the inhibitory effect of these monoterpenes confirmed the inhibition of the growth of 25 microorganisms, including animal and plant pathogens, besides saprophytic fungi, such as Aspergillus flavus and the dermatophytous fungus Trichophyton rubrum (Adan et al., 1998; Dorman and Deans, 2000).

The antimicrobial potential of more than 280 plant species has already been investigated against several species of Aspergillus, and approximately 100 of them showed some inhibitory activity over the production of mycotoxins and fungus growth. Thymus and Origanum, which possessed thymol and carvacrol, completely inhibited A. flavus, Penicillium digitatum, $P$. italicum, Botrytis cinerea and Alternaria citri, the parasites of seeds and fruits (Montes-Belmont and Carvajal, 1998; Arras and Usai, 2001). Thymol reduced the percentage of contamination by A. flavus to $43.7 \%$ and $75 \mathrm{ppm}$ of carvacrol were enough to reduce the 
mycelial radial growth of $P$. digitatum from $74 \mathrm{~mm}$ in the control treatment to $5 \mathrm{~mm}$.

Recently, the observation that the antimicrobial action is due to the presence of thymol and carvacrol in the oils that have them as main constituents has been reinforced. Three species of Thymus were assessed, with relation to the antifungical activity and T. mastichina, deprived from thymol and carvacrol, presented reduced inhibitory activity against $C$. albicans (Pina-Vaz et al., 2004).

The efficiency of the oil of $L$. gracilis in the inhibition of the microorganisms assessed in this work agree Lippia performed by Pascual et al. (2001), in which the essential oils of the species showed in their majority antimicrobial activity, though there was a certain variation with respect to the inhibition response in different species of microorganisms. The $L$. sidoides, for example, showed inhibitory activity against $E$. coli, $S$. aureus, B.subtilis and Mycobacterium smegmatis, but low activity against Pseudomonas aeruginosa and against some microorganisms located in the human epithelial tract (Lacoste et al., 1996).

Studies regarding the mechanism of action of the essential oils over microorganisms showed that the monoterpenes acted on the cell membrane. The essential oil of oregano, as well as their constituents, thymol and carvacrol, accumulated over the cell membrane of $P$. aeruginosa and $S$. aureus resulting in the increase of the permeability of $90 \%$ of the cells of these microorganisms (Lambert et al, 2001). Besides altering the structure of the cell membrane, these volatiles break the molecules of intracellular nucleic acids. The antimicrobial action of the essential oils could also be related to the inactivation of some enzymes, including those involved in the production of energy and synthesis of structural components (Lambert et al. 2001).

Arras and Usai (2001), after treatment with Thymus oil and the main constituent, carvacrol, morphological alterations of hyphae and conidia of $P$. digitatum observed the through electronic microscopy. Through laser microscopy, alterations in the structure of the membrane such as to increase permeability were observed, which was an important factor in the mechanism of antimicrobial action (Lambert et al, 2001). Membrane damage was also confirmed by the coloring of $C$. albicans cells with iodine-based dye. The substance penetrated cells, whose membranes were damaged by the exposure to the
Thymus oil and its main components. The mechanism of action of the chemical substances involves a primary lesion of the membrane, with inherent cell death. As a result of the structural disorganization of the membrane, quick discharge of potassium was observed (Pina-Vaz et al., 2004). With regards to the results obtained in this research, it was concluded that essential oils rich in thymol and carvacrol, in general, inhibited the growth of microorganisms. This inhibition capability of these compounds represented in a certain way an extension of the very role they played in the plants, defending them from phytopathogenic microorganisms. Due to the antimicrobial potential, the essential oil of $L$. gracilis could represent an alternative to chemical and pharmaceutical industries in the manipulation of new products with greater asepsis potential. Besides the absence of chemical residues after their use, these aromatic substances are not offensive to the environment or to the people that manipulate them (Stammati et al., 1999; Daferera et al., 2003).

\section{ACKNOWLEDGMENTS}

This work was carried out with the support of the CNPq. We thank Dr. Maria Menezes, Dr. Itamar S. Melo and Dr. Isabelle Meunier for microorganism identification and statistic analysis.

\section{RESUMO}

Avaliou-se a atividade antimicrobiana do óleo essencial (OE) de Lippia gracilis Schauer sobre fungos contaminantes de laboratórios de cultura de tecidos vegetais e bactérias endofíticas de helicônias. Discos de micélio dos fungos Geotrichum candidum; Trichoderma viride; Torula herbarum; Paecillomyces sp.; Aspergillus nidulans; Fusicoccum sp.; A. flavus; $P$. aeruginens; Curvularia lunata e A. niger, foram inoculados em meio BDA com óleo $(0 ; 420 ; 440$; 460; 480 e $500 \mu \mathrm{L} \mathrm{L}^{-1}$ ). O percentual de inibição em $420 \mu \mathrm{L} \mathrm{L}^{-1}$ foi de $100 \%$ para todos os fungos exceto para $C$. lunata and $A$. niger, o qual foi de $95.58 \%$ and $89.40 \%$ respectivamente. Em outro experimento, suspensão das espécies Salmonela choleraceuis-diarizonae, Enterobacter asburiae, Bacillus thuringiensis, B. pumilus, Klebsiella 
pneumoniae, E. hormaechei, Bacillus pumilus, B. cereus, B. pumilus foi individualmente adicionada ao meio NYDA, que foi vertido em placas de Petri e, após solidificado, perfurado e preenchido com água ou óleo $\left(420 \mu \mathrm{L} \mathrm{L}^{-1}\right)$. Avaliou-se o diâmetro do halo de inibição. Avaliou-se também, a inibição em meio líquido. K. pneumoniae foi a espécie bacteriana menos sensível e E. hormaechei foi a mais sensível.

\section{REFERENCES}

Adam, K.; Sivropoulou, A.; Kokkini, S.; Lanaras, T. and Arsenakis, M. (1998), Antifungal activities of Origanum vulgare subsp. Hirusutum, Mentha spicata, Lavanula angustifolia and Salvia fruticosa essential oils against human pathogenic fungi. Journal Agriculture Food Chemistry, 46, 1739-1745.

Ahmed, S.; Kapadia, Z. and Badar, Y. (1994), Antibacterial activity of Salvia santolinifolia. Fitoterapia, 65 : (3), 271-272.

Arras, G. and Usai, M. (2001), Fungitoxic activity of 12 oils against four postharvest citrus pathogens: Chemical analysis of Thymus capitatus oil and its effect in subatmospheric pressure conditions. Journal of Food Protection, 64 : (7), 1025-1029.

Bakholdina, S. I.; Krasikova, I. N.; Buzoleva, L. S.; Shubin, F. N. and Solov'era, T. F. (2001), Effects of culture method and growth phase on free lipid composition of Yersinia pseudotuberculosis. Biochemistry, 66 : (4), 415-421.

Boatto, G.; Pintore, G. and Palomba, M. (1994), Composition and antibacterial activity of Inula Helenium and Rosmarinus officinalis essential oils. Fitoterapia, 65 : (3), 279-280.

Capó, Y. A. (1998), Propagación y Mejora Genética de Plantas por Biotecnologia. In: Ponce, J. N. P. P. (Eds). Instituto de Biotecnologia de las Plantas, Santa Clara: Cuba. pp. 81-104.

Daferera, D. J.; Ziogas, B, N. and Polissiou, M. G. (2003), The effectiveness of plant essential oils on the growth of Botrytis cinerea, Fusarium sp. and Clavibacter michiganensis subsp. Michiganensis. Crop Protection, 22, 39-44.

Demetzos, C.; Perdetzoglou, D. K. and Tan, K. (2001), Composition and antimicrobial studies of the oils of Origanum calcaratum Juss. and O. Scabrum Boiss. et Heldr. form Greece. Journal of Essential Oil Research, 13, 460-462.

Dias, M. and Rodrigues P. H. V. (2001), Fontes de explantes e contaminantes isolados em cultivo in vitro de helicônia. Revista Brasileira de Horticultura Ornamental, 7 : (2), 165-168.
Dorman, H. J. and Deans, S. G. (2000), Antimicrobial agents from plants: Antibacterial activity of plant volatile oils. Journal Applied Microbiology, 88, 308-316.

Dwivedi, S. K. and Singh, K. P. (1998), Fungitoxicity of some higher plant products against Macrophomina phaseolina (Tassi) Goid. Flavour and Fragrance Jounal, 13, 397-399.

Edington, L. V.; Khew, K. L. and Barron, G. L. (1971), Fungitoxic espectrum of benzimidazole compounds. Phytopathology, 61 : (1), 42-44.

Grattapaglia, D. and Machado, M. A. (1998), Micropropagação In: Torres, A. C. and Caldas, S. L. (Eds). Técnicas de aplicação da cultura de tecidos de plantas. Brasília: ABCTP/ EMBRAPA - CNPH, pp. 99-169.

Isman, B. M. (2000), Plant essential oils for pest and disease management. Crop Protection, 19, 603-608.

Lacoste, E.; Chaumont, J. P.; Mandin, D.; Plumel, M. M. and Matos, F. J. (1996), Antiseptic properties of essential oil of Lippia sidoides Cham. Application to the cutaneeous microflora. Annales Pharmaceutiques Françaises, 54, 228-230.

Lambert, R. J. W.; Sjandamis, P. N.; Coote, P. J. and Nychas, G. J. E. (2001), A study of the minimum inhibitory concentration and mode of action of oregano essential oil, thymol and carvacrol. Journal of Applied Microbiology, 91, 453-462.

Leifert, C.; Morris, C. E. and Waites, W. M. (1994), Ecology of microbial saprophytes ans pathogens in tissue culture and field-grow plants: reasons for contamination problems in vitro. Critical Reviews in Plant Science, 13 : (2), 139-183.

Leifert, C. and Woodward, S. (1998), Laboratory contamination management: the requirement for microbiological quality assurance. Plant Cell, Tissue and Organ Culture, 52, 83-88.

Levin, R.; Stav,R.; Alper, Y. and Watad, A. A. (1996), In vitro multiplication in liquid culture of Syngonium contaminated with Bacillus spp. and Rathayibacter tritici, Plant Cell, Tissue and Organ Culture, 45, 277-280.

Lindsay, E. A.; Berry, Y.; Jamie, F. J. and Bremner, J. B. (2000), Antibacterial compounds from Carissa Lanceolata R. Br. Phytochemistry, 55 : (2), 403-406.

Manohar, V.; Ingram, C.; Gray, J.; Talpur, N. A.; Echard, B. W.; Bagchi, D. and Preuss, H. G. (2001), Antifungal activities of Origanum oil against Candida albicans. Molecular and Cellular Biochemistry, 228, 111-117.

Matos, F. J. A.; Machado, M. I. L.; Craveiro, A. A.; Alencar, J. W. and Silva, M. G. V. (1999), Medicinal plants Northeast Brazil containing Thymol and Carvacrol-Lippia sidoides Cham. and L. gracillis $\mathrm{H}$. B. K (Verbenaceae). Journal of Essential Oil Research, Wheaton, 11, 666-668. 
Menezes, M. and Silva-Hanlin, D. M. (1997), Guia prático para fungos fitopatogênicos. Recife: UFRPE. $106 \mathrm{pp}$.

Montes-Belmont, R. and Carvajal, M. (1998), Control of Aspergillus flavus in maize with plant essential oils and their components. Journal of Food Protection, 61 : (5), 616-619.

Murashige, T. and Skoog, F. (1962), A revised medium for rapid growth and bioassay with tobacco tissue cultures. Physiologia Plantarum, 15, 473-497.

Nannetti, D. C. (1994), Utilização da cultura de tecidos vegetais na micropropagação e manutenção de Heliconia sp. PhD Thesis, High School of Lavras, Lavras, Brasil.

Niedz, R. P. (1998), Using isothiazolone biocides to control microbial and fungal contaminants in plant tissue cultures. Hortechnology, 8 : (4), 598-601.

Niedz, R. and Baushier, M. G. (2002), Control in vitro contamination of explants from greenhouse and fieldgrown trees. In Vitro Cell Development Biology, 38, 468-471.

Pascual, M. E.; Slowing, K.; Carretero, E.; Sánchez Mata, D. and Villar, A. (2001), Lippia: traditional uses, chemistry and pharmacology: a rewie. Journal of Ethnopharmacology, 76, 201-214.

Periago, P. M.; Palop, A. and Fernández, P. S. (2002), Combined effect of nisin, carvacrol and thymol on the viability of Bacillus cereus heat-treated vegetative cells. Food Sci. Tech Int., 7 : (6), 487-492.

Pina-Vaz, C.; Rodrigues, A. G.; Pinto, E.; Oliveira, S. C.; Tavares, C.; Salgueiro, L.; Cavaleiro, C. and Gonçalves, M. (2004), Antifungal activity of Thymus oils and their major compounds. Journal of the European Academy of Dermatology and Venereology, 18, 73-78.

Pusey, P. L. and Wilson, C. L. (1984), Postharvest biological control of stone fruit brown rot by Bacillus subtilis. Plant disease, 68 : (9), 753-756.

Rassoli, I. and Mirmostafa, S. A. (2003), Bacterial susceptibility to and chemical composition of essential oils from Thymus kotschyanus and Thymus persicus. Jounal of Agricultural and Food Chemistry, 51, 2200-2205.
Reddy, M. V.; Angers, P.; Gosselin, A. and Arul, J. (1997), Characterization and use of essential oil from Thymus vulgaris against Botrytis cinerea and Rhizopus stolonifer in strawberry fruits. Phytochemistry, 47 : (8), 1515-1520.

Reddy, V. L. N.; Ravikanth, V.; Rao, T. P.; Diwan, P. V. and Venkateswarlu, Y. (2001), A new triterpenoid from the fern Adiantum lunulatum and evaliation of antibacterial activity. Phytochemistry, 56 : (2), 173-175.

Rios, J. L.; Recio, M. C. and Villar, A. (1988), Screening methods for natural products with antimicrobial activity: A review of the literature. Journal of thmopharmacology, 23, 127-149.

Santos, M. H. L. C. (1999), Avaliação do efeito de bactérias promotoras de crescimento no cultivo in vitro e em casa-de-vegetação de Heliconia psittacorum L. F. PhD Thesis, Federal Rural University of Pernambuco, Recife, Brasil.

Sokmen, A.; Gulluce, M.; Akpulat, A. H.; Daferera, D.; Tepe, B.; Polissiou, M.; Sokmen, M. and Sahin, F. (2004), The in vitro antimicrobial and antioxidant activities of the essential oils and methanol extracts of endemic Thymus spathulifolius, Food Control, 15, 627-634.

Stammati, A.; Bonsi, P.; Zucco, F.; Moezelaar, R.; Alakomi, H. L. and Wright, A. (1999), Toxicity of selected plant volatilis in microbial and mammalian short-term assays. Food and chemical toxicology, 37, 813-823. 